Г. П. Сябренко ${ }^{1,2}$, I. І. Кириченко ${ }^{3,4}$, А. С. Шкляр ${ }^{5}$, Г. А. Терещенко Е. О. Приходько ${ }^{6}$ А. О. Деміхов ${ }^{6}$

КНП «Кіровоградський обласний клінічний госпіталь ветеранів війни» ${ }^{1}$ Донеиький національний медичний університет МОЗ Украйни ${ }^{2}$ Харківська медична академія післядипломної освіти МОЗ України Військово-медичний клінічний иентр Північного регіону Міністерства оборони України Харківський національний медичний університет МОЗ Украйни Сумський державний університет МОН України

\title{
ПСИХОЛОГІЧНІ ТА МЕТАБОЛІЧНІ ОСОБЛИВОСТІ ОСІБ МОЛОДОГО ВІКУ 3 АРТЕРІАЛЬНОЮ ГІПЕРТЕНЗІЄЮ І СТУПЕНЯ ТА ДИСГАРМОНІЙНОЮ ЖИРОВОЮ КОМПОНЕНТОЮ МАСИ ТІЛА
}

Психологічні та метаболічні особливості осіб молодого віку з артеріальною гіпертензією I ступеня та дисгармонійною жировою компонентою маси тіла Г. П. Сябренко ${ }^{1,2}$, І. І. Кириченко ${ }^{3,4}$, А. С. Шкляр ${ }^{5}$, Г. А. Терещенко ${ }^{6}$, Е. О. Приходько ${ }^{6}$ А. О. Деміхов ${ }^{6}$ КНП «Кіровоградський обласний клінічний госпіталь ветеранів війни» ${ }^{1}$

Донецький національний медичний університет МОЗ України ${ }^{2}$

Харківська медична академія післядипломної освіти МОЗ України ${ }^{3}$

Військово-медичний клінічний центр Північного регіону Міністерства оборони України ${ }^{4}$

Харківський національний медичний університет МОЗ України ${ }^{5}$

Сумський державний університет МОН України

Резюме. Профрілактика артеріальної гіпертензії $(A Г)$ є менш вартісним і значно безпечнішим процесом, ніж такі інтервенції, як аортокоронарне шунтування $i$ діаліз, необхідність в яких може виникнути при не виявленні та безсимптомному перебігу АГ. Проблема виявлення молодих людей із АГ на ранньому етапі, стратифрікація серцево-судинного ризику (ССР), індивідуальний підбір адекватної терапії, а також упровадження профрілактичних заходів щодо найпоширеніших фракторів ССР, у тому числі з надмірною масою тіла (НMT), на етапі первинної ланки медичної допомоги потребує подальшого вивчення.

Мета дослідження - вивчити клініко-метаболічні особливості осіб молодого віку з АГ I ступеня та НMT.

Матеріали і методи. У дослідженні обстежено 74 пацієнти у віці 18-44 роки з веріфікованим діагнозом АГ I ступеня та НМТ, яких поподілили на дві клінічні групи, залежно від рівня ССР (21 пацієнт із низьким ССР (нССР), та 53 особи з помірним ССР (пССР). Після підписання інфрормованої згоди пацієнта, на основі аналізу скарг,
Psychological and metabolic features of young people with stage 1 hypertension and disgarmonious fat component

G. P. Siabrenko 1,2 I. I. Kyrychenko ${ }^{3,4}$, A. S. Shklyar ${ }^{5}$, G. A. Tereshchenko ${ }^{6}$, E. O. Prykhodko ${ }^{6}$, A. O. Demikhov ${ }^{6}$ Kirovohrad Regional Clinical Hospital of War Veterans ${ }^{1}$

Donetsk National Medical University ${ }^{2}$

Kharkiv Medical Academy of Postgraduate

Education $^{3}$

Military Medical Clinical Center of the Northern

Region

Ministry of Defense of Ukraine 4

Kharkiv National Medical University ${ }^{5}$

Sumy State University ${ }^{6}$

e-mail:n.demyhova@med.sumdu.edu.ua

Summary. Prevention of hypertension is a less expensive and much safer process than interventions such as coronary artery bypass grafting and dialysis, which may be required in the absence and detection of asymptomatic hypertension. The problem of identifying young people with hypertension at an early stage, stratification of cardiovascular risk (CVR), individual selection of adequate therapy, as well as the introduction of preventive measures against the most common factors of CVR, including overweight (OW) at the primary care stage help needs further study.

The aim of the study - to learn the clinical and metabolic characteristics of young people with stage 1 hypertension and OW.

Materials and Methods. The study examined 74 patients aged 18-44 years with a verified diagnosis of hypertension stage I and BMI, who were divided into two clinical groups, depending on the level of SVR (21 patients with low CVR (LCVR), and 53 patients with moderate CVR (MCVR). After signing informed consent of the patient, based on the analysis of complaints, anamnesis, physical and laboratory methods 
анамнезу, фрізикальних та лабораторних методів обстеження, ультразвукового дослідження та визначення рівня ССР, респондентів поділили на дві групи. При обчисленні ССР за допомогою онлайн-калькулятора розраховували сумарний ССР за рівнем САТ, ЗХ, ЛПВЩ та статусом тютюнокуріння, а також ССР за IMT. Оцінку АТ виконували шляхом вимірювання САТ і ДАТ механічним приладом MicrolifeBPAG1-20 (Швейцарія). При вимірюванні антропометричних показників визначали масу тіла (ке), зріст (м). На основі цих параметрів обчислювали індекс маси тіла (IMT) і оцінювали ступінь ожиріння.

Результати. При клініко-лабораторному обстеженні пацієнтів молодого віку з АГ I ступеня та НMT, яких поділили на осіб з низьким серцево-судинним (нССР) та помірним серцево-судинним ризиком (пССР), з'ясовано, що:

- частота ранніх серцево-судинних захворювань серед батьків хворих, яку достовірно $(p<0,001)$ частіше реєстрували в групі з помірним ССР, ніж серед пацієнтів із низьким ССР (відповідно серед $(98,1 \pm 1,9) \%$ та $(61,9 \pm 10,6) \%$ пацієнтів, $p<0,001)$;

- підвищення рівня вмісту загального холестерину (3X) у сироватці крові понад 5,0 ммоль/дм³ виявлено серед $(96,2 \pm 2,6) \%$ пацієнтів з пССР та достовірно $(p<0,001)$ менш часто в групі з нССР - серед $(61,9 \pm 10,6) \%$ осіб;

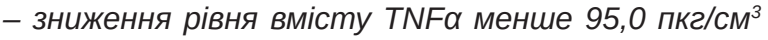
виявлено серед $(73,6 \pm 6,1) \%$ пацієнтів із помірним ССР та достовірно $(p<0,01)$ менш часто в групі з нССР - серед $(28,6 \pm 9,9) \%$ осіб, що пояснюється меншою частотою осіб з більш високими показниками IMT. Визначено математичну фрункціональну залежність між вмістом TNFа та IMT і обґрунтовано номограму оцінювання TNF $\alpha$ залежно від IMT;

- виявлено більш високі рівні вмісту лептину серед $(81,1 \pm 5,4) \%$ пацієнтів із пССР та достовірно $(p<0,01)$ менш часто в групі з нССР - серед $(38,1 \pm 10,6) \%$ осіб. Визначено математичну фрункціональну залежність між вмістом лептину сироватки крові та IMT і обірунтовано номограму оцінювання лептину залежно від IMT.

Висновки. Зростання ССР у хворих на АГ I ступеня та НМТ пов'язане з низкою ФР та метаболічними особливостями пацієнтів. Результати аналізу фракторів-кандидатів для оцінювання ССР показали, що з 23 клініко-лабораторних та анамнестичних ознак лише для 7-ми з них властиві достовірні $(p<0,05)$ прогностичні показники стосовно оцінки ССР у молодому віці за наявності АГ I ступеня у поєднанні з НMT.

Ключові слова: артеріальна гіпертензія; надмірна маса тіла; молодий вік; серцево-судинний ризик.

\section{ВСТУП}

Настановою European Guidelineson cardiovascular disease preventionin clinical practice (2016) визначено, що превентивні заходи щодо серцево-судинних захворювань (ССЗ) повинні здійснюватись в усіх медичних установах, у тому числі в закладах первинної медичної допомоги, і підкреслено, що значущість лікаря загальної практики в їх реалізації має становити понад 90 \% від усіх консультацій пацієнтів у більшості країн $[1,5]$.

Особливу увагу привертає збільшення захво- of monitoring, ultrasound examination and determination level of the CVR respondents were divided into two groups. When determining CVR using an online calculator calculated the total CVR at the level of SBP, HDLP and smoking status, as well as the CVR for BMI. Evaluation of blood pressure was performed by measuring SBP and DBP with mechanically device MicrolifeBPAG1-20 (Switzerland). When measuring anthropometric indicators we determined body weight $(\mathrm{kg})$, height $(m)$. Based on these parameters, the body mass index(BMI) and assessed the degree of obesity.

Results. Clinical and laboratory examination of young patients with stage 1 hypertension and OW, divided into persons with low cardiovascular (ICVR) and moderate cardiovascular risk ( $m C V R$ ) found that:

- frequency of early cardiovascular diseases among parents of patients (severe heredity); significantly ( $p$ <0.001) more often it was registered in the group of patients with moderate CVR than among patients with low

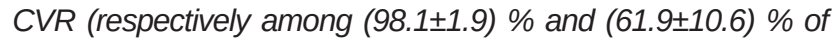
patients, $p<0.001$ )

- an increase in the level of total cholesterol $(\mathrm{CH})$ in the serum over $5.0 \mathrm{mmol} / \mathrm{dm} 3$ was found among (96.2 2.6$) \%$ of patients with mCVR and significantly $(p<0.001)$ less often in the group with ICVR - among (61.9 \pm 10.6$) \%$ of persons

- a decrease in the level of TNF- $\alpha$ less than $95.0 \mathrm{pkg} / \mathrm{cm} 3$ was found among $(73.6 \pm 6.1) \%$ of patients with moderate CVR and significantly $(p<0.01)$ less often

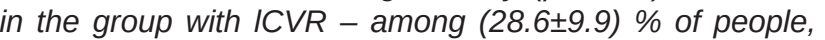
due to the lower frequency of people with higher CVR. The mathematical functional dependence between the content of TNF- $\alpha$ and BMI is determined and the nomogram of TNF- $\alpha$ estimation depending on CVR is substantiated

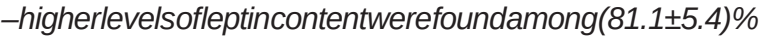
of patients with $m C V R$ and significantly $(p<0.01)$ less often in the group with low CVR - among (38.1 10.6$) \%$ of persons. The mathematical functional dependence between serum leptin content and BMI was determined and the nomogram of BMI dependent leptin evaluation was substantiated.

Conclusions. The increase of CVR in patients with stage I hypertension and OW is associated with a number of risk factors and metabolic characteristics of patients. Analysis of candidate factors for the assessment of CVR revealed that of the 23 clinical-laboratory and anamnestic signs, only 7 of them have reliable $(p<0.05)$ prognostic indicators for the assessment of CVR at a young age in the presence of stage 1 hypertension in combination with OW.

Key words: arterial hypertension; overweight; young age; cardiovascular risk.

рюваності на артеріальну гіпертензію (АГ) серед молодих людей працездатного віку. За оцінками експертів підвищений АТ $є$ причиною 9 млн смертельних випадків щорічно [6]. Цей ризик може значно знизитися при ранній діагностиці та упровадженні відповідних методів профрілактики. Профрілактика АГ є менш вартісним і значно безпечнішим процесом, ніж такі інтервенції, як аортокоронарне шунтування і діаліз, необхідність в яких може виникнути при невиявленні та безсимптомному перебігу АГ $[2,5]$. 
Проблема виявлення молодих людей з артеріальною гіпертензією на ранньому етапі, стратифрікація серцево-судинного ризику, індивідуальний підбір адекватної терапії, а також упровадження профрілактичних заходів щодо найпоширеніших фракторів серцево-судинного ризику (ССР), у тому числі ожиріння на етапі первинної ланки медичної допомоги залишається дискутабельним та потребує подальшого вивчення [3, 4, 7].

Метою дослідження було вивчити клініко-метаболічні особливості осіб молодого віку з АГ І ступеня та надмірною масою тіла (НMT).

\section{МАТЕРІАЛИ I МЕТОДИ}

У дослідженні обстежено 74 пацієнти у віці 1844 роки з вериорікованим діагнозом АГ І ступеня та НMT, яких поподілили на дві клінічні групи, залежно від рівня ССР (21 пацієнт із низьким ССР (нСCP) та 53 особи з помірним ССР (пССР). Після підписання інфрормованої згоди пацієнта, на основі аналізу скарг, анамнезу, фрізикальних та лабораторних методів обстеження, ультразвукового дослідження та визначення рівня ССР, респондентів поділили на дві групи. При обчисленні ССР за допомогою онлайн-калькулятора розраховували сумарний ССР за рівнем САТ, 3Х, ЛПВЩ та статусом тютюнокуріння, а також ССР за ІМТ. Оцінку АТ виконували шляхом вимірювання САТ і ДАТ механічним приладом MicrolifeBPAG1-20 (Швейцарія). При вимірюванні антропометричних показників визначали масу тіла (кг), зріст (м). На основі цих параметрів обчислювали індекс маси тіла (IMT) і оцінювали ступінь ожиріння. Згідно із загальноприйнятими рекомендаціями, нормальними показниками IMT вважали

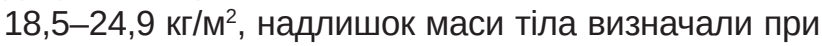

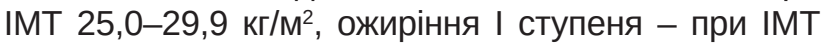

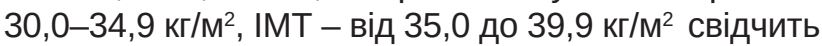
про ожиріння II ступеня, та ожиріння III ступеня ви-

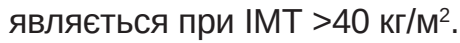

Визначення показників ліпідного обміну здійснювали методом спектрофотометрії автоматичним біохімічним аналізатором OlympusAU 640 (Японія, 2006). Відповідно до рекомендацій Європейського товариства кардіологів (ESC) та Європейського товариства гіпертензії (ESH) (2013) та Української асоціації кардіологів, діагностично значимими проявами дисліпідемії вважали збільшення рівня тригліцеридів (ТГ) >1,7ммоль/л, загального холестерину (3X) >5,0 ммоль/л, загального холестерину ліпопротеїдів низької щільності (3Х лПнЩ) >3,0 ммоль/л, та зменшення рівня загального холестерину ліпопротеїдів високої щільності (3Х ЛПВЩ) $<1,1$ ммоль/л для чоловіків та $<1,2$ ммоль/л для жінок, індекс атерогенності (IA) ->3,0. IA розраховували за фрормулою: $\mathrm{IA}=(3 \mathrm{X}-3 \mathrm{X}$ лпВщ) / 3Х лпВщ.
Визначення рівня TNFa здійснювали за допомогою імуноферментного набору для кількісного визначення людського загального фрактора некрозу пухлин альфра (TNFa), категорія № BMS2034/ BMS2034TEN, виробник BenderMedSystemsGmbH, Австрія, на аналізаторі імуноферментному MSR1000, виробник - «AwarenessTechnology» (США). Рефрерентні значення показників TNFa: 82-103 пг/ мл. Аналіз гормону жирової тканини - лептину визначали у сироватці крові імуноферментним методом за допомогою набору для кількісного визначення лептину (LEPTIN) сироватки людини, категорія № CAN-L-4260 (Німеччина) на аналізаторі імуноферментному MSR-1000, виробник «Awareness Technology» (США).

\section{РЕЗУЛЬТАТИ Й ОБГОВОРЕННЯ}

Аналіз найпоширеніших модифікованих ФР виявив, що пацієнти молодого віку з АГ І стадії та НМТ $(81,1 \pm 4,6) \%$ мають несприятливі харчові звички, $(63,5 \pm 5,6) \%$ характеризуються гіподинамією, $(56,8 \pm 5,8) \%$ - курять та $(54,1 \pm 5,8) \%$ мають прояви стресу. 3 перерахованих фракторів, залежно від статі, виявлені достовірні відмінності за частотою несприятливих харчових звичок: серед чоловіків - $(93,0 \pm 3,4) \%$, серед жінок - у $(41,2 \pm 11,9)$ $\%$, р<0,05 (табл. 1).

Групи порівняння (нССР та пССР) достовірно не відрізнялися поміж собою за частотою аналізованих поведінкових фракторів та однак відрізнялись за рівнем ССР. Серед пацієнтів з АГ І ступеня та НМТ питома вага осіб з пССР та з наявністю інтенсивного куріння ( $I_{k}>110$ пачко/років) достовірно перевищувала відповідний показник групи 3 нССР (відповідно 77,6 та 26,7 \%, p<0,01). Аналіз інтенсивності куріння (середня кількість цигарок на добу) виявив, що пацієнти з нССР та пССР відрізняються лише за питомою вагою осіб, які викурюють понад 15 цигарок на добу (КГ1 - 24,1\%; КГ2 $42,0 \%, p<0,01)$, а також за питомою вагою осіб, що викурюють менше 5 цигарок на добу (контроль КГ1 - 22,8 \%; КГ2 - 9,8 \%, p<0,05).

Серед 74 осіб молодого віку 3 АГ І ступеня та НMT, 28 пацієнтів із пССР та 19 пацієнтів з нССР зазначали наявність хронічних стресових ситуацій у повсякденному житті. Серед цих 47 осіб дослідили рівні особистісної та реактивної тривожності (метод Ч. Д. Спілбергер у модифікації Ю. Л. Ханіна), а також рівень депресії (опитувальник Зунга) та рівень стресостійкості (методом Холмса та Раже, яким опосередковано визначається ступінь стресу, рівень стресу та соціальну адаптацію особистості).

Більш несприятливо вищим виявився ступінь стресостійкості серед 28 пацієнтів 3 пССР, який становив $(163,8 \pm 11,3)$ бала, що значно вище порівняно $з$ групою 19 пацієнтів із нССР - $(50,3 \pm 9,4)$ бала $(p<0,01)$. 
Таблиця 1. Частота окремих клініко-анамнестичних фракторів серед осіб молодого віку з артеріальною гіпертензією І ступеня та надмірною масою тіла залежно від статі й рівня серцево-судинного ризику

\begin{tabular}{|c|c|c|c|c|c|}
\hline \multirow{2}{*}{\multicolumn{2}{|c|}{$\begin{array}{c}\text { Клінічна та статева група } \\
\text { пацієнтів залежно від рівня ССР }\end{array}$}} & \multicolumn{4}{|c|}{ Клініко-анамнестичний фактор } \\
\hline & & \multirow{2}{*}{$\begin{array}{c}\begin{array}{c}\text { куріння, } \\
\mathrm{P} \pm \mathrm{m} \%\end{array} \\
56,8 \pm 5,8\end{array}$} & \multirow{2}{*}{$\frac{\text { стрес, } \mathrm{P} \pm \mathrm{m} \%}{54,1 \pm 5,8}$} & \multirow{2}{*}{$\begin{array}{c}\begin{array}{c}\text { гіподинамія, } \\
\text { P } \pm \mathrm{m} \%\end{array} \\
63,5 \pm 5,6\end{array}$} & \multirow{2}{*}{$\begin{array}{c}\text { харчові погрішності, } \\
\text { P } \pm \text { m\% } \\
81,1 \pm 4,6\end{array}$} \\
\hline Разом & загалом (n=74) & & & & \\
\hline & чоловіки $(\mathrm{n}=57)$ & $59,6 \pm 6,5$ & $59,7 \pm 6,0$ & $66,7 \pm 6,2$ & $93,0 \pm 3,4^{\mathrm{a}}$ \\
\hline & жінки $(\mathrm{n}=17)$ & $47,1 \pm 12,1$ & $58,8 \pm 11,9$ & $52,9 \pm 12,1$ & $41,2 \pm 11,9$ \\
\hline \multirow[t]{3}{*}{$\mathrm{HCCP}$} & КГ1 (n=21) & $52,4 \pm 10,9$ & $57,1 \pm 10,8$ & $61,9 \pm 10,6$ & $76,2 \pm 9,3$ \\
\hline & чоловіки $(\mathrm{n}=11)$ & $63,6 \pm 14,5$ & $54,4 \pm 15,0$ & $72,7 \pm 13,4$ & 100,0 \\
\hline & жінки $(\mathrm{n}=10)$ & $40,0 \pm 15,5$ & $60,0 \pm 15,5$ & $50,0 \pm 15,8$ & $50,0 \pm 15,8$ \\
\hline \multirow[t]{3}{*}{$\Pi \mathrm{CCP}$} & КГ2 (n=53) & $58,5 \pm 6,8$ & $65,1 \pm 7,3$ & $62,4 \pm 6,6$ & $83,0 \pm 5,2$ \\
\hline & чоловіки $(\mathrm{n}=46)$ & $58,7 \pm 7,3$ & $52,2 \pm 7,4$ & $65,2 \pm 7,0$ & $91,3 \pm 4,2$ \\
\hline & жінки $(\mathrm{n}=7)$ & $57,1 \pm 18,7$ & $57,1 \pm 18,7$ & $57,1 \pm 18,7$ & $28,6 \pm 17,1$ \\
\hline
\end{tabular}

Примітки: 1) а - достовірна відмінність показника залежно від статі у межах клінічної групи, на рівні р<0,05;

2) пССР - помірний серцево-судинний ризик;

3) нССР - низький серцево-судинний ризик;

4) НМТ - надмірна маса тіла. Важливим показником виявився запропонований індексний показник тривалості куріння, який ми запропонували, порівняно з тривалістю життя (частка прожитих років з курінням): оскільки цей індекс характеризує частку життя, вільного від куріння. 3'ясовано, що питома вага пацієнтів зі значеннями цього індексу понад 0,4 од. - достовірно вища (нССР - 52,6 \%; пССР - 74,1 \%, р<0,05).

Також вищий рівень реактивної тривожності діагностовано при нССР, він становив $(54,1 \pm 0,97)$ бала на тлі меншого особистісного занепокоєння

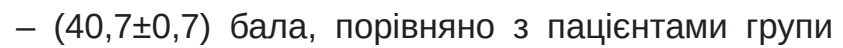
пССР - $(46,7 \pm 1,3)$ бала $(p<0,01)$ та $(46,1 \pm 2,1)$ бала $(p<0,05)$ відповідно, що може бути свідченням високого рівня тривожності як підґрунтя прогресування ССР (табл. 2).

Пацієнти молодого віку з АГ I ступеня та НМТ, залежно від рівня ССР також відрізнялись за індексом стресостійкості (при нССР - 50,3ะ9,4; при пССР - 163,8 $\pm 11,3)$ та рівнем субдепресії та де-

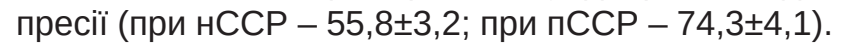
Зважаючи та високі значення індексу стресостійкості пацієнтів із пССР, можна констатувати високу частоту осіб з низьким рівнем соціальної адаптації, а також стану, близького до депресії (субдепресія), та, власне, депресії. Наведене свідчить на користь потреби осіб молодого віку з АГ І ступеня на тлі НМТ у медико-психологічній підтримці на первинному рівні медичної допомоги.

Аналіз вмісту ЗХ виявив, що серед хворих молодого віку з АГ । ступеня та НМТ $(5,81 \pm 0,14)$ ммоль/л та достовірно відрізнявся від показника контрольної групи - $(4,64 \pm 0,03)$ ммоль/л та залежно від рівня ССР, складаючи відповідно $(5,46 \pm 0,24)$ ммоль/л - при нССР та $(5,96 \pm 0,14)$ ммоль/л - при
пССР $(p<0,05)$. Необхідно зауважити, що залежно від статі обстежених, рівень 3 коливався від $(5,98 \pm 0,16)$ ммоль/л-серед чоловіків до $(5,23 \pm 0,25)$ ммоль/л - серед жінок $(\mathrm{p}<0,05)$.

Вміст ТГ серед хворих на АГ I ступеня та НМТ коливався у межах $(2,27 \pm 0,14)$ ммоль/л і достовірно $(p<0,05)$ відрізнявся від показника пацієнтів контрольної групи - $(1,36 \pm 0,02)$ ммоль/л та залежно від рівня ССР, складаючи відповідно $(1,92 \pm 0,22)$ ммоль/л - при нССР та $(2,42 \pm 0,13)$ ммоль/л - при пССР. Залежно від статі обстежених рівень 3 Х коливався від $(2,56 \pm 0,18)$ ммоль/л - серед чоловіків до $(1,32 \pm 0,10)$ ммоль/л - серед жінок (р<0,01) (табл. 3).

Вміст ЛПВЩ серед хворих молодого віку з АГ । ступеня та НМТ коливався у межах $(1,12 \pm 0,03)$ ммоль/л та значно $(p<0,01)$ відрізнявся від показника пацієнтів контрольної групи - $(1,23 \pm 0,02)$ ммоль/л і залежно від рівня ССР, складаючи відповідно $(1,21 \pm 0,06)$ ммоль/ - при нССР та $(1,09 \pm 0,03)$ ммоль/л - при пССР. Залежно від статі обстежених рівень $3 Х$ коливався від $(1,05 \pm 0,02)$ ммоль/л - серед чоловіків до $(1,37 \pm 0,06)$ ммоль/л - серед жінок $(p<0,001)$.

Вміст ЛПНЩ серед хворих молодого віку з АГ । ступеня та НМТ коливався у межах $(3,81 \pm 0,11)$ ммоль/л та значно $(p<0,01)$ відрізнявся від показника пацієнтів контрольної групи - $(2,63 \pm 0,03)$

Таблиця 2. Показники тривожності депресії та стресостійкості осіб молодого віку з артеріальною гіпертензією I ступеня та надмірною масою тіла залежно від рівня серцево-судинного ризику

\begin{tabular}{l|c|c|c|c}
\hline $\begin{array}{c}\text { Клінічна група пацієнтів } \\
\text { залежно від рівня ССР }\end{array}$ & $\begin{array}{c}\text { Особистісна } \\
\text { тривожність }\end{array}$ & $\begin{array}{c}\text { Реактивна } \\
\text { тривожність }\end{array}$ & $\begin{array}{c}\text { Індекс стресостійкості } \\
\text { (Холмс, Раже) }\end{array}$ & $\begin{array}{c}\text { Індекс депресії } \\
\text { (Зунга) }\end{array}$ \\
\hline нССР - КГ1 $(\mathrm{n}=19)$ & $40,7 \pm 0,7$ & $54,1 \pm 0,97$ & $50,3 \pm 9,4$ & $55,8 \pm 3,2$ \\
\hline пССР - КГ2 $(\mathrm{n}=28)$ & $46,7 \pm 1,3^{\mathrm{a}}$ & $46,1 \pm 2,1^{\mathrm{a}}$ & $163,8 \pm 11,3^{6}$ & $74,3 \pm 4,1^{\mathrm{a}}$ \\
\hline
\end{tabular}

Примітки: 1) а - достовірна відмінність показника залежно від рівня ССР, при $\mathrm{p}<0,05$;

2) ${ }^{6}$ - достовірна відмінність показника залежно від рівня ССР, при $\mathrm{p}<0,01$. 
Таблиця 3. Показники ліпідного профілю осіб молодого віку з артеріальною гіпертензією I ступеня та надмірною масою тіла залежно від статі й рівня серцево-судинного ризику

\begin{tabular}{|c|c|c|c|c|c|c|c|}
\hline \multicolumn{2}{|c|}{$\begin{array}{c}\text { Клінічна та статева група } \\
\text { пацієнтів залежно від ССР }\end{array}$} & $\begin{array}{c}3 \mathrm{X} \\
\text { ммоль/л }\end{array}$ & $\begin{array}{c}\text { ТГ, } \\
\text { ммоль/л }\end{array}$ & $\begin{array}{l}\text { ЛПВЩ, } \\
\text { ммоль/л }\end{array}$ & $\begin{array}{l}\text { ЛПНЩ, } \\
\text { ммоль/л }\end{array}$ & $\begin{array}{l}\text { ЛПДНЩ, } \\
\text { ммоль/л }\end{array}$ & IA \\
\hline \multirow[t]{3}{*}{ Разом } & загалом (n=74) & $5,81 \pm 0,14^{a}$ & $2,27 \pm 0,14^{6}$ & $1,12 \pm 0,03^{6}$ & $3,81 \pm 0,11^{a}$ & $0,85 \pm 0,05^{6}$ & $4,42 \pm 0,16^{6}$ \\
\hline & чоловіки (n=57) & $5,98 \pm 0,16$ & $2,56 \pm 0,18$ & $1,05 \pm 0,02$ & $3,96 \pm 0,12$ & $0,92 \pm 0,06$ & $4,87 \pm 0,17$ \\
\hline & жінки $(\mathrm{n}=17)$ & $5,23 \pm 0,25$ & $1,32 \pm 0,10$ & $1,37 \pm 0,06$ & $3,28 \pm 0,20$ & $0,61 \pm 0,04$ & $2,86 \pm 0,16$ \\
\hline \multirow[t]{3}{*}{$\mathrm{HCCP}$} & КГ1 (n=21) & $5,46 \pm 0,24$ & $1,92 \pm 0,22^{a}$ & $1,21 \pm 0,06^{a}$ & $3,48 \pm 0,18$ & $0,69 \pm 0,05$ & $3,52 \pm 0,28$ \\
\hline & чоловіки $(n=11)$ & $5,70 \pm 0,39$ & $2,54 \pm 0,42$ & $1,06 \pm 0,06$ & $3,68 \pm 0,29$ & $0,79 \pm 0,10$ & $4,62 \pm 0,5$ \\
\hline & жінки $(\mathrm{n}=10)$ & $5,19 \pm 0,29$ & $1,30 \pm 0,12$ & $1,38 \pm 0,09$ & $3,26 \pm 0,21$ & $0,58 \pm 0,06$ & $2,83 \pm 0,18$ \\
\hline \multirow[t]{3}{*}{ пССР } & КГ2 (n=53) & $5,96 \pm 0,14$ & $2,42 \pm 0,13^{a}$ & $1,09 \pm 0,03^{a}$ & $3,95 \pm 0,11$ & $0,92 \pm 0,04^{a}$ & $4,69 \pm 0,18^{6}$ \\
\hline & чоловіки $(\mathrm{n}=46)$ & $6,05 \pm 0,17$ & $2,56 \pm 0,20$ & $1,05 \pm 0,03$ & $4,04 \pm 0,13$ & $0,95 \pm 0,07$ & $4,93 \pm 0,18^{c}$ \\
\hline & жінки $(\mathrm{n}=7)$ & $5,30 \pm 0,52$ & $1,35 \pm 0,20$ & $1,37 \pm 0,07$ & $3,32 \pm 0,43$ & $0,67 \pm 0,06$ & $2,92 \pm 0,33$ \\
\hline
\end{tabular}

Примітки: 1) а - достовірна відмінність показника залежно від статі у межах клінічної групи, на рівні p<0,05;

2) ${ }^{6}$ - достовірна відмінність показника залежно від статі у межах клінічної групи, на рівні $p<0,01$;

3) ${ }^{c}$ - достовірна відмінність показника у чоловіків КГ1 та КГ2, на рівні $p<0,05$;

4) ${ }^{d}$ - достовірна відмінність показника жінок КГ1 та КГ2, на рівні p<0,05

ммоль/л і залежно від рівня ССР складав відповідно $(3,48 \pm 0,18)$ ммоль/л - при нССР та $(3,95 \pm 0,11)$ ммоль/л - при пССР. Залежно від статі обстежених рівень ЛПНЩ коливався від $(3,96 \pm 0,12)$ ммоль/л серед чоловіків до $(3,28 \pm 0,20)$ ммоль/л - серед жінок $(\mathrm{p}<0,001)$.

Вміст ЛПДНЩ серед хворих молодого віку з АГ । ступеня та НМТ коливався у межах $(0,85 \pm 0,05)$ ммоль/л та значно ( $<<0,01)$ відрізнявся від показника пацієнтів контрольної групи - $(0,62 \pm 0,10)$ ммоль/л і залежно від рівня ССР складаючи відповідно $(0,69 \pm 0,05)$ ммоль/л - при нССР та $(0,92 \pm 0,04)$ ммоль/л - при пССР. Залежно від статі обстежених рівень лПдНщ коливався від $(0,92 \pm 0,06)$ ммоль/л - серед чоловіків до $(0,61 \pm 0,04)$ ммоль/ - серед жінок $(p<0,001)$.

Індекс (коефіцієнт) атерогенності хворих молодого віку з АГ І ступеня та НМТ коливався у межах $(4,42 \pm 0,16)$ од. та значно $(p<0,01)$ відрізнявся від показника пацієнтів контрольної групи - $(2,38 \pm 0,05)$ од. і залежно від рівня ССР, складаючи відповідно $(3,52 \pm 0,28)$ од. - при нССР та $(4,69 \pm 0,18)$ од. - при пССР. Залежно від статі обстежених IA коливався від $(4,87 \pm 0,17)$ од. - серед осіб чоловічої статі до $(2,86 \pm 0,16)$ од. - серед жінок $(p<0,001)$.

Показники вуглеводного та пуринового обмінів серед осіб молодого віку з АГ І ступеня та НМТ залежали від рівня ССР.

Вміст глюкози плазми крові у хворих молодого віку з АГ I ступеня та НМТ коливався у межах $(4,92 \pm 0,08)$ ммоль/л та дещо відрізняючись залежно від рівня ССР, складаючи відповідно $(4,50 \pm 0,10)$ ммоль/л - при нССР та $(5,10 \pm 0,07)$ ммоль/л - при пССР, не перевищуючи значення референтних показників. Залежно від статі обстежених виявлено достовірно вищий його рівень у осіб чоловічої статі 3 більш високим ССР: при нССР - $(4,30 \pm 0,10)$ ммоль/л, при пССР - $(5,14 \pm 0,13)$ ммоль/л, $р<0,05)$ (рис.).

Рівень інсуліну плазми крові у хворих молодого віку з АГ І ступеня та НМТ коливався у межах
$(11,30 \pm 0,58)$ мкОД/мл та достовірно був більш високим серед осіб чоловічої статі, як при нССР (чоловіки - $(12,53 \pm 1,29)$ мкОД/мл, жінки - $(7,49 \pm 0,48)$ мкОД/мл, р<0,05), так і при пССР (чоловіки $(12,37 \pm 0,82)$ мкОД/мл, жінки - $(8,94 \pm 1,36)$ мкОД/ мл, p<0,05). Аналогічною закономірністю більш високих показників $(p<0,05)$ у чоловіків порівняно 3 жінками характеризувався і НОМА-індекс.

Вміст сечової кислоти як у чоловіків, так і жінок молодого віку з АГ І ступеня та НМТ не перевищував рефрерентних значень, рекомендованих для оцінювання цього показника Європейською асоціацією кардіологів, однак характеризувався більш високими рівнями в осіб чоловічої статі як при нССР (чоловіки - $(370,6 \pm 17,8)$ мкмоль/л, жінки $(338,5 \pm 22,6)$ мкмоль/л, p>0,05), так і при пССР (чоловіки - $(394,6 \pm 8,8)$ мкмоль/л, жінки $(273,3 \pm 24,4)$ мкмоль/л, р<0,001) (табл. 4).

Показники стану системного запалення та лептину в осіб молодого віку з АГ І ступеня та НМT.

Вивчення рівнів гормону жирової тканини серед 74 хворих молодого віку з АГ І ступеня та НМТ виявило коливання його вмісту в межах $(16,91 \pm 0,97)$ нг/дм³ ${ }^{3}$ Зі зростанням рівня ССР визначена тенденція (табл. 5) до зменшення рівня

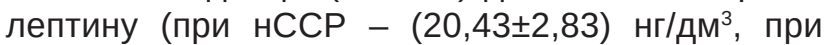
пССР - $(15,51 \pm 1,25)$ нг/дм $\left.{ }^{3}, p>0,05\right)$. Однак зважаючи на різнорідність за IMT цих клінічних груп, ми виявили динаміку змін ЛП залежно від IMT та з'ясовано, що ця закономірність характеризується наступним аналітичним виразом: ЛП = 0,003 ${ }^{3}$ - 0,4x² + 14,83x - 171,2; при високій точності відтворення цієї закономірності - на рівні $\mathrm{R}^{2}=0,999$, де $\mathrm{x}$ - градація IMT.

Вивчення рівнів TNFa серед 74 хворих молодого віку з АГ І ступеня та НМТ виявило коливання його вмісту у межах $(170,6 \pm 11,8)$ пг/дм³ ${ }^{3}$ що зважаючи та опубліковані референтні значення [82-103 пг/мл], значно їх перевищує. 


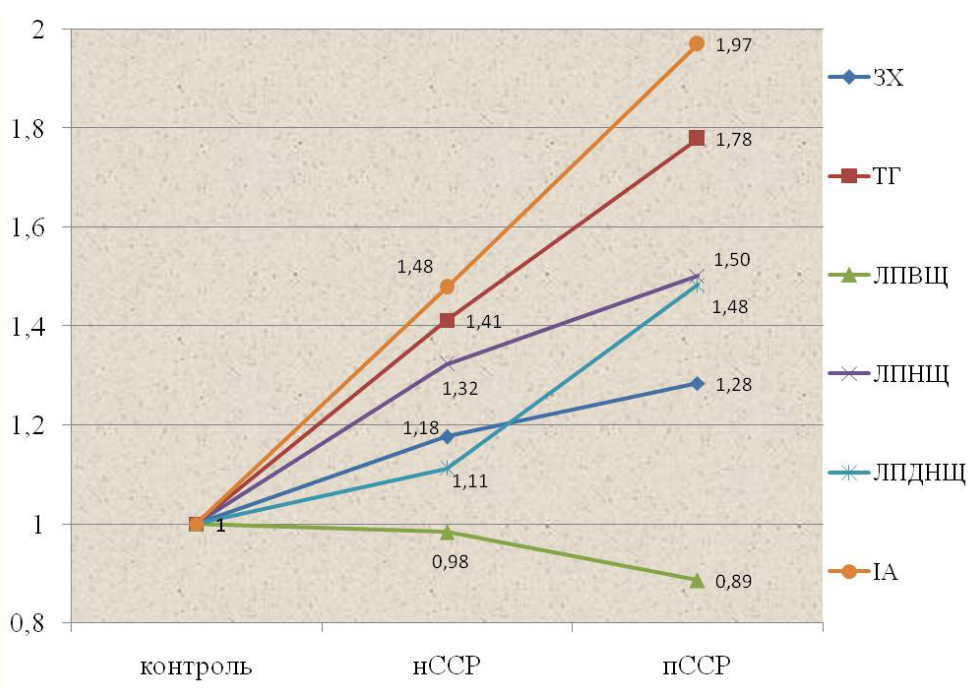

Рис. Стандартизовані показники ліпідного профілю хворих молодого віку на артеріальну гіпертензію I ступеня та надмірною масою тіла залежно від рівня серцево-судинного ризику.

Таблиця 4. Показники вуглеводного та пуринового обмінів серед осіб молодого віку з артеріальною гіпертензією I ступеня та надмірною масою тіла залежно від статі й рівня серцево-судинного ризику

\begin{tabular}{l|l|c|c|c|c}
\hline $\begin{array}{c}\text { Клінічна та статева група пацієнтів } \\
\text { залежно від рівня ССР }\end{array}$ & $\begin{array}{c}\text { Глюкоза, } \\
\text { ммоль/дм }\end{array}$ & $\begin{array}{c}\text { Інсулін, } \\
\text { мкОД/мл }\end{array}$ & НОМА-індекс & $\begin{array}{c}\text { Сечова кислота, } \\
\text { мкмоль/л }\end{array}$ \\
\hline \multirow{2}{*}{ Разом } & загалом $(\mathrm{n}=74)$ & $4,92 \pm 0,08$ & $11,30 \pm 0,58$ & $2,50 \pm 0,14$ & $370,4 \pm 7,9$ \\
\cline { 2 - 6 } & чоловіки $(\mathrm{n}=57)$ & $4,97 \pm 0,11$ & $12,39 \pm 0,71^{\mathrm{a}}$ & $2,78 \pm 0,17^{\mathrm{a}}$ & $389,9 \pm 7,9^{\mathrm{a}}$ \\
\cline { 2 - 6 } & жінки $(\mathrm{n}=17)$ & $4,76 \pm 0,13$ & $8,09 \pm 0,55$ & $1,71 \pm 0,13$ & $311,7 \pm 18,4$ \\
\hline \multirow{2}{*}{ нССР } & КГ1 $(\mathrm{n}=21)$ & $4,50 \pm 0,10$ & $9,88 \pm 0,77$ & $1,93 \pm 0,14$ & $354,6 \pm 14,3$ \\
\cline { 2 - 6 } & чоловіки $(\mathrm{n}=11)$ & $4,30 \pm 0,10^{\mathrm{a}}$ & $12,53 \pm 1,29^{\mathrm{a}}$ & $2,35 \pm 0,26^{\mathrm{a}}$ & $370,6 \pm 17,8$ \\
\cline { 2 - 6 } & жінки $(\mathrm{n}=10)$ & $4,71 \pm 0,18$ & $7,49 \pm 0,48$ & $1,56 \pm 0,1$ & $338,5 \pm 22,6$ \\
\hline \multirow{2}{*}{ ССР } & КГ2 $(\mathrm{n}=53)$ & $5,10 \pm 0,07$ & $11,87 \pm 0,55$ & $2,73 \pm 0,11$ & $376,9 \pm 8,5$ \\
\cline { 2 - 6 } & чоловіки $(\mathrm{n}=46)$ & $5,14 \pm 0,13$ & $12,37 \pm 0,82^{\mathrm{a}}$ & $2,87 \pm 0,2^{\mathrm{a}}$ & $394,6 \pm 8,8^{6}$ \\
\cline { 2 - 6 } & жінки $(\mathrm{n}=7)$ & $4,82 \pm 0,17$ & $8,94 \pm 1,36$ & $1,94 \pm 0,33$ & $273,3 \pm 24,4$ \\
\hline
\end{tabular}

Примітки: 1) а - достовірна відмінність показника залежно від статі у межах клінічної групи на рівні р<0,05;

2) ${ }^{6}$ - достовірна відмінність показника залежно від статі у межах клінічної групи на рівні p<0,01.

Таблиця 5. Показники стану системного запалення та гормону жирової тканини - лептину серед осіб молодого віку з артеріальною гіпертензією I ступеня та надмірною масою тіла залежно від статі й рівня серцево-судинним ризиком

\begin{tabular}{|c|c|c|c|c|}
\hline \multicolumn{2}{|c|}{$\begin{array}{c}\text { Клінічна та статева група пацієнтів залежно від } \\
\text { рівня ССР }\end{array}$} & $\begin{array}{c}\text { Лептин, } \\
\text { нг/дм }\end{array}$ & $\begin{array}{l}\text { TNFa, } \\
\text { пг/мл }\end{array}$ & $\begin{array}{l}\text { СРБ, } \\
\mathrm{Mг} / \mathrm{AM}^{3}\end{array}$ \\
\hline \multirow[t]{3}{*}{ Разом } & загалом $(\mathrm{n}=74)$ & $16,91 \pm 0,97$ & $170,6 \pm 11,8$ & $2,73 \pm 0,25$ \\
\hline & чоловіки (n=57) & $16,21 \pm 1,01$ & $183,0 \pm 16,6^{a}$ & $2,57 \pm 0,23$ \\
\hline & жінки $(\mathrm{n}=17)$ & $19,24 \pm 2,82$ & $128,8 \pm 7,4$ & $3,25 \pm 0,86$ \\
\hline \multirow[t]{3}{*}{$\mathrm{HCCP}$} & КГ1 $(\mathrm{n}=21)$ & $20,43 \pm 2,83$ & $288,7 \pm 66,9$ & $3,24 \pm 0,71$ \\
\hline & чоловіки $(\mathrm{n}=11)$ & $18,19 \pm 3,19$ & $438,5 \pm 163,5^{a}$ & $2,75 \pm 0,66$ \\
\hline & жінки $(\mathrm{n}=10)$ & $22,9 \pm 5,11$ & $123,9 \pm 13,1$ & $3,79 \pm 1,44$ \\
\hline \multirow[t]{3}{*}{ пCСР } & КГ2 (n=53) & $15,51 \pm 1,25$ & $123,7 \pm 40,6$ & $2,53 \pm 0,25$ \\
\hline & чоловіки $(\mathrm{n}=46)$ & $15,74 \pm 1,02$ & $121,9 \pm 5,3^{a}$ & $2,53 \pm 0,25$ \\
\hline & жінки $(\mathrm{n}=7)$ & $14,00 \pm 1,52$ & $135,7 \pm 5,8$ & $2,54 \pm 0,85$ \\
\hline
\end{tabular}

Примітки: 1) а - достовірна відмінність показника залежно від статі у межах клінічної групи на рівні р<0,05;

2) пССР - помірний серцево-судинний ризик;

3) нССР - низький серцево-судинний ризик;

4) НМТ - надмірна маса тіла. 
Виявлено достовірні відмінності залежно від статі обстежених (чоловіки - $(183,0 \pm 16,6)$ пг/мл, жінки - $(128,8 \pm 7,4)$ пг/мл, $p<0,05)$ та залежно від рівня ССР (при нССР - $(288,7 \pm 66,9)$ пг/мл, при пССР - $(123,7 \pm 40,6)$ пг/мл, р<0,01).

Однак зважаючи на різнорідність за IMT цих клінічних груп, ми виявили закономірність змін TNFa залежно від IMT та з'ясували, що ця закономірність характеризується наступним аналітичним виразом: TNF $=0,013 x^{3}-1,659 x^{2}+66,43 x-734,7$; при високій точності відтворення цієї закономірності - на рівні $\mathrm{R}^{2}=0,993$, де $\mathrm{x}$ - градація IMT.

Для оцінки стану судинної стінки і вираження атеросклеротичного ураження усім хворим проводили дуплексне сканування СА з виконанням функціонального навантаження та, відповідно, з розрахунком показника \%dBA, значення якого серед 74 хворих молодого віку з АГ І ступеня та НМТ коливався у межах $(14,8 \pm 0,6) \%$ і не залежали від статі пацієнтів (чоловіки - $(14,8 \pm 0,7) \%$, жінки - $(14,6 \pm 1,2)$ $\%$, p $>0,05)$ та рівня ССР (нССР - $(15,9 \pm 1,2) \%$, пССР - $(14,4 \pm 0,7) \%, p>0,05)$. Однак ми виявили динаміку змін \%dBА залежно від ІМТ та з'ясовано, що ця характеризується наступним аналітичним виразом: $\% d B A=0,001 x^{3}-0,113 x^{2}+3,721 x-23,42(\%)$; $\mathrm{R}^{2}=0,960$, при достатньо високій точності відтворення $-\mathrm{R}^{2}=0,960$, де $\mathrm{x}$ - градація IMT.
Вміст маркерів судинної адгезії (VCAM-1), який визначали в сироватці крові у хворих молодого віку 3 АГ । ступеня та НМТ коливався у межах $(1401,2 \pm 68,6)$ нг/см³ та був дещо більш вищим серед осіб чоловічої статі при нССР, ніж при пССР (відповідно $(1800,4 \pm 410,4)$ нг/см ${ }^{3}$ та $(1328,7 \pm 73,4)$

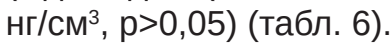

Серед осіб жіночої статі - коливався у межах $(1338,8 \pm 98,1)$ нг/см³ та достовірно не відрізнявся залежно від рівня ССР (при нССР $(1355,5 \pm 161,3)$ нг/см ${ }^{3}$, при пССР - $(1315,0 \pm 110,2)$ $\left.\mathrm{Hг} / \mathrm{cm}^{3}, \mathrm{p}>0,05\right)$. Наведене можна пояснити значною варіативністю цього показника та можливою залежністю від інших фракторів (непередбачуваного відбору), наприклад ступеня вираження HМT. Саме тому ми виконали динамічний (поліномінальний аналіз) вмісту VCAM-1 залежно від IMT і виявили, що залежність між ними характеризується наступним аналітичним виразом: VCAM $=-1,422 x^{2}+125,6 x-1126\left(\right.$ нг/см $\left.{ }^{3}\right)$, при точності відтворення на рівні $\mathrm{R}^{2}=0,783$, де x - градація IMT.

Перспективи подальших досліджень пов'язані 3 оцінкою ефективності різних програм терапевтичної корекції/зниження ССР шляхом усунення/ модиорікації фракторів ССР на первинному рівні надання медичної допомоги.

Таблиця 6. Показники функції ендотелію та комплексу інтима-медіа серед осіб молодого віку з артеріальною гіпертензією I ступеня та надмірною масою тіла залежно від статі й рівня серцево-судинного ризику

\begin{tabular}{|c|c|c|c|c|c|}
\hline \multicolumn{2}{|c|}{ Клінічна та статева група } & $\begin{array}{c}\text { TKIM } \\
\text { ліва, мм }\end{array}$ & $\begin{array}{c}\text { TKIM } \\
\text { права, мм }\end{array}$ & $\begin{array}{c}\mathrm{d} \text { БА } \\
\%\end{array}$ & $\begin{array}{l}\text { VCAM, } \\
\mathrm{H} / \mathrm{CM}^{3}\end{array}$ \\
\hline \multirow[t]{3}{*}{ Разом } & загалом (n=74) & $0,81 \pm 0,02^{6}$ & $0,74 \pm 0,02$ & $14,8 \pm 0,6$ & $1401,2 \pm 68,6$ \\
\hline & чоловіки $(n=57)$ & $0,78 \pm 0,02^{a}$ & $0,73 \pm 0,02$ & $14,8 \pm 0,7$ & $1419,8 \pm 86,4$ \\
\hline & жінки $(\mathrm{n}=17)$ & $0,91 \pm 0,05^{6}$ & $0,78 \pm 0,04$ & $14,6 \pm 1,2$ & $1338,8 \pm 98,1$ \\
\hline \multirow[t]{3}{*}{$\mathrm{HCCP}$} & КГ1 $(\mathrm{n}=21)$ & $0,86 \pm 0,06$ & $0,76 \pm 0,03$ & $15,9 \pm 1,2$ & $1588,6 \pm 207,1$ \\
\hline & чоловіки $(\mathrm{n}=11)$ & $0,75 \pm 0,04^{a}$ & $0,69 \pm 0,03$ & $16,2 \pm 1,4$ & $1800,4 \pm 410,4$ \\
\hline & жінки $(\mathrm{n}=10)$ & $0,98 \pm 0,13$ & $0,84 \pm 0,06$ & $15,6 \pm 2,2$ & $1355,5 \pm 161,3$ \\
\hline \multirow[t]{3}{*}{$\Pi \mathrm{CCP}$} & КГ2 (n=53) & $0,79 \pm 0,02^{6}$ & $0,73 \pm 0,01$ & $14,4 \pm 0,7$ & $1326,9 \pm 126,4$ \\
\hline & чоловіки $(n=46)$ & $0,79 \pm 0,01^{6}$ & $0,74 \pm 0,01^{a}$ & $14,5 \pm 0,8$ & $1328,7 \pm 73,4$ \\
\hline & жінки $(\mathrm{n}=7)$ & $0,81 \pm 0,05$ & $0,69 \pm 0,02$ & $13,6 \pm 1,2$ & $1315,0 \pm 110,2$ \\
\hline
\end{tabular}

Примітки: 1) а - достовірна відмінність показника залежно від статі у межах клінічної групи на рівні р<0,05;

2) ${ }^{6}$ - достовірна відмінність показника залежно від сторони виміру на рівні $p<0,05$.

\section{ВИСНОВКИ}

Зростання ССР у хворих на АГ І ступеня та НМТ пов'язано з низкою ФР та метаболічними особливостями пацієнтів. Аналіз фракторів-кандидатів для оцінювання ССР виявив, що 323 клініко-лабораторних та анамнестичних ознак лише для 7-ми 3 них властиві достовірні $(p<0,05)$ прогностичні показники стосовно оцінки ССР у молодому віці за наявності АГІ ступеня у поєднанні з НМТ. Найбільш значимі 3 них:

- частота ранніх серцево-судинних захворювань серед батьків хворих (обважченої спадковос- ті); що достовірно ( $p<0,001)$ частіше її реєстрували в групі пацієнтів з помірним ССР, ніж серед пацієнтів 3 низьким ССР (відповідно серед $(98,1 \pm 1,9) \%$ та $(61,9 \pm 10,6) \%$ пацієнтів, $р<0,001)$;

- підвищення рівня вмісту загального холестерину (3X) у сироватці крові понад 5,0 ммоль/дм ${ }^{3}$ виявлено серед $(96,2 \pm 2,6) \%$ пацієнтів із пССР та достовірно $(p<0,001)$ менш часто в групі із нССР серед $(61,9 \pm 10,6) \%$ осіб;

- зниження рівня вмісту TNFa менше 95,0 пкг/ $\mathrm{cm}^{3}$ виявлено серед $(73,6 \pm 6,1) \%$ пацієнтів 3 помірним ССР та достовірно ( $p<0,01)$ менш часто в групі 
3 нССР - серед $(28,6 \pm 9,9)$ \% осіб, що пояснюється меншою частотою осіб з більш високими показниками IMT. Визначено математичну фуункціональну залежність між вмістом TNFa та IMT і обґрунтовано номограму оцінювання TNFa залежно від IMT;

- виявлено більш високі рівні вмісту лептину

\section{СПИСОК ЛІТЕРАТУРИ}

1. Рудь О. М. Артеріальна гіпертензія у осіб молодого віку з ожирінням: клініко-анамнестичні особливості, значимі для оцінювання кардіоваскулярного ризику / О. М. Рудь // Хірургія Донбасу. - 2019. - № 4. - С. 48-56.

2. Хіміон Л. В. Артеріальна гіпертензія у пацієнтів молодого віку з ожирінням: основні фрактори ризику / Л. В. Хіміон, О. М. Рудь // Здоров'я суспільства. - 2016. - № 3-4. - C. 81-86.

3. Assesment of the lipid profile correction in patients with arterial hypertension and type 2 diabetes mellitus / O. Chernatska, N. Demikhova, T. Rudenko, A. Demikhov // Azerbaijan Medical Journal. - 2019. - No. 1. - P. 95-99.

4. Arterial hypertension prevention as an actual medical and social problem / O. Demikhov, I. Dehtyarova, O. Rud

\section{REFERENCES}

1. Rud OM. [Arterial hypertension in young people with obesity: clinical and anamnestic features important for assessing cardiovascular risk]. Khirurhiia Donbasu. 2019; 4: 48-56. Ukrainian.

2. Khimion LV, Rud OM. [Hypertension in young obese patients: the main risk factors]. Zdorovia suspilstva. 2016;34: 81-6. Ukrainian

3. Chernatska O, Demikhova N, Rudenko T, DemikhovA. Assesment of the lipid profile correction in patients with arterial hypertension and type 2 diabetes mellitus. Azerbaijan Medical Journal; 2019;1: 95-9.

4. Demikhov O, Dehtyarova I, Rud O. Arterial hypertension prevention as an actual medical and social problem. Bangladesh Journal of Medical Science. серед $(81,1 \pm 5,4)$ \% пацієнтів 3 пССР та достовірно $(p<0,01)$ менш часто в групі 3 нССР - серед $(38,1 \pm 10,6) \%$ осіб. Визначено математичну фрункціональну залежність між вмістом лептину сироватки крові та IMT і обґрунтовано номограму оцінювання лептину залежно від IMT.

[et al.] // Bangladesh Journal of Medical Science. - 2020. Vol. 19 (4). - P. 722-729. DOI: https://doi.org/10.3329/bjms. v19i4.46632.

5. European Guidelines on cardiovascular disease prevention in clinical practice. European Heart Journal. 2016. - Vol. 3 (37). - P. 2315-2381

6. Predictive value of updating Framingham risk scores with novel risk markers in the U.S. General population / B. S. Ferket, B. J. van Kempen, M. G. Hunink [et al.] // PLoS One. - 2014. - Vol. 9, No. 2. - P. 883-912.

7. Khimion L. High blood pressure in young adults with obesity: the main risk factors / L. Khimion, O. Rud, M. Rybytska // Massachusetts Review of Science and Technologies. - 2016. - No. 1 (13). - P. 884-891.

2020;19(4): 722-9. DOI: https://doi.org/10.3329/bjms v19i4.46632.

5. European Guidelines on cardiovascular disease prevention in clinical practice. European Heart Journal, 2016;3(37): 2315-81.

6. Ferket BS, van Kempen BJ, Hunink MG. Predictive value of updating Framingham risk scores with novel risk markers in the U.S. General population. PLoS One. 2014;9(2): 883-912.

7. Khimion L, Rud O, Rybytska M. High blood pressure in young adults with obesity: the main risk factors. Massachusetts Review of Science and Technologies. 2016;1(13): 884-91. 